\title{
臨床
}

\section{口腔癌進行症例に対する超選択的動注化学療法と 放射線照射併用療法の経験}

\author{
大矢亮一池村邦男大成宣 弘* \\ 中田肇*
}

\begin{abstract}
要旨：カルボプラチンの超選択的動脈内投与と放射線照射並びに UFT®を併用する治療法を口腔癌 の進展例 2 症例に行った。動注は Seldinger 法により大腿動脈からカテーテルを挿入して外頸動脈造 影（DSA）を行い，腫瘍の支配動脈よりカルボプラチンを one-shot で投与した。

症例 1 は舌癌 T3N2bM0 (stage IV) で, カルボプラチン700mg 動注（原発巣に450mg,リンパ節 転移巣に $250 \mathrm{mg}$ ）と放射線（X線） $30 \mathrm{~Gy}$ を照射し，UFT ${ }^{\circledR} 600 \mathrm{mg}$ を連日投与した。原発巣は $\mathrm{CR}$, 頸部転移巣は NC であった。切除材料の病理組織学的検索で原発巣に腫瘍細胞は認められなか ったが，頸部リンパ節には viable な腫瘍細胞が認められた。

症例 2 は頓粘膜癌 T4N1M0 (stage IV) で，カルボプラチン600mg 動注と放射線（X線）60Gy 照 射, UFT ${ }^{\circledR} 400 \mathrm{mg}$ を連日投与した。原発巣，頸部転移巣ともに CR となった。手術は行わなかった。 両症例ともに治療後 1 年を経過しており, 再発, 転移の微候を認めていない。本治療法の著しい抗 腫瘍効果, 比較的軽微な副作用は口腔の進展癌に対して有力な治療法であると考える。しかし, 本治 療法を行らにあたっては DSA を行える施設とスタッフを必要とすること，支配血管の確実な同定 ができない場合は有効性が予測できない，等の問題点がある。
\end{abstract}

キーワード：口腔進展癌，超選択的動注療法，カルボプラチン，放射線療法，UFT ${ }^{\circledR}$ 内服

\section{緒 言}

口腔癌の局所進展症例に拡大根治手術を施行し た場合，口腔機能と形態保存に関しては満足のい く結果が得られ難い。他方，プラチナ誘導体の静 脈内投与と放射線治療の併用により治療成績の改 善が報告されているが，進展例では局所制御が困 難な場合も少なからず経験している。動注療法は 高濃度の薬剤を腫瘍組織に到達させ，全身的な毒 性を軽減させ得る方法である。従来の頭頸部癌に 対する動注療法は浅側頭動脈からの持続動注療法 が主であり，カテーテルのトラブルや患者の日常 生活の制限などの問題がある。

今回，われわれは口腔癌の局所進展症例に対す る治療成績の向上を目的として, Seldinger 法で
大腿動脈からカテーテルを挿入して外頸動脈を造 影し，腫瘍の支配動脈よりカルボプラチン（以下 $\mathrm{CBDCA}$ と略）を投与する超選択的動注化学療 法と，UFT ${ }^{\circledR}$ 内服投与と放射線照射併用療法を 進展口腔癌 2 症例に対して行った。一次治療効果 は良好であり，その概要を報告する。

\section{動 注方法}

Seldinger 法により大腿動脈からカテーテルを 挿入し, 外頸動脈造影 (Digital Subtraction Angiography，以下 DSA と略）を行い，原発腫瘍 と転移リンパ節の支配血管を同定し，カテーテル を超選択的に挿入した。支配血管が複数の場合に は薬剤総投与量を支配動脈の本数で適宜分割し, 持続注入器により約20分間で動注した。動注終了

産業医科大学歯科口腔外科（主任：池村邦男教授）

* 産業医科大学放射線科 (主任 : 中田 肇教授)

[1996年 7 月 26 日受付，1996年 9 月 21 日受理〕 
後に血管内膜保護の目的でステロイド剤（ソルメ ドロール125mg）の注入を行った。血管造影上動 注は本学放射線科に抢いて施行された。

\section{使用薬剂}

CBDCA を体表面積当たり $350 \mathrm{mg}$ 投与した。 CBDCA の投与前後で制吐目的に塩酸グラニセ トロン（カイトリル®）を投与した。治療期間中は UFT ${ }^{\circledR} 400$ ないし $600 \mathrm{mg} /$ 日 が内服投与された。

\section{放射線療法}

4 ないし $6 \mathrm{MV} \mathrm{X}$ 線を 1 回 $1.5 \mathrm{~Gy} ， 1$ 日 2 回， 週 5 日照射する accelerated fractionation 照射が 行われた。また，放射線照射開始日より口内炎対 策としてエレース ${ }^{\circledR}$ アイスボールを1日3回含嗽 させた。

\section{治療効果と副作用の判定}

治療効果と副作用の程度は日本癌治療学会の固 形がん化学療法効果の判定基準により判定した。

\section{症例}

症例 1 : 55歳, 男性。舌癌, 組織学的には中等 度分化型扁平上皮癌で， T3N2bM0 (写真 1,2 ， 3 )であった。6 MV X線を $(1.5+1.5) \mathrm{Gy} /$ 日， 5 回/週，照射野 $10 \times 11 \mathrm{~cm}$ で総量30Gy 外部照射 乙, CBDCA $700 \mathrm{mg}$ の動注と UFT ${ }^{\circledR} 600 \mathrm{mg} /$ 日 を連日内服投与した。

DSA 所見：原発腫瘍は舌動脈より血流を受け ていた。転移顎下リンパ節は顔面動脈, 上深頸部 の転移リンパ節は後頭動脈と上行咽頭動脈の分枝

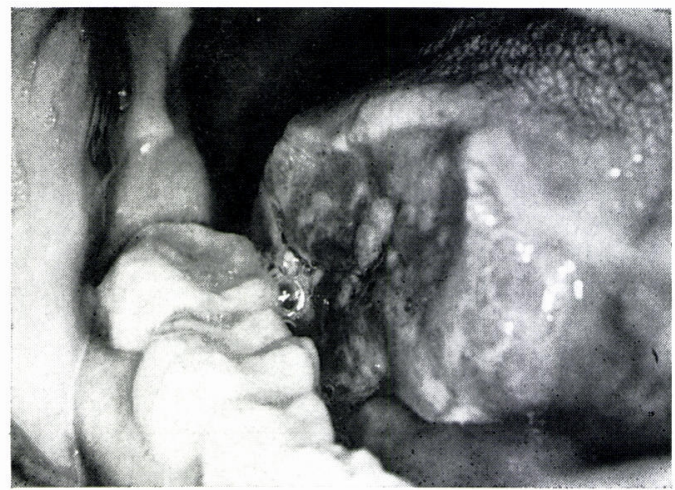

写真 1 右舌縁部に潰瘍型腫瘍を認める。

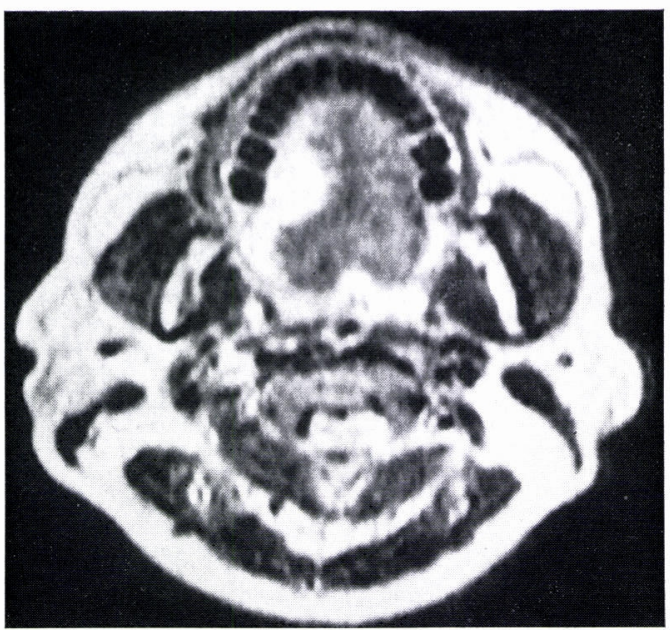

写真 2 治療前 MRI（T2 強調画像）

右舌縁部に正中に㧍よぶ高信号域を認める。

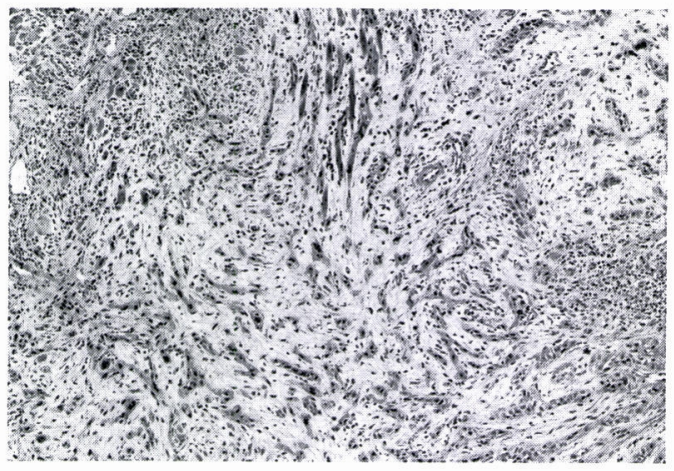

写真 3 腫瘍が小胞巣を形成し, びまん性に浸潤し ている。(pattern of invasion, Anneroth 分類 Grade 4)

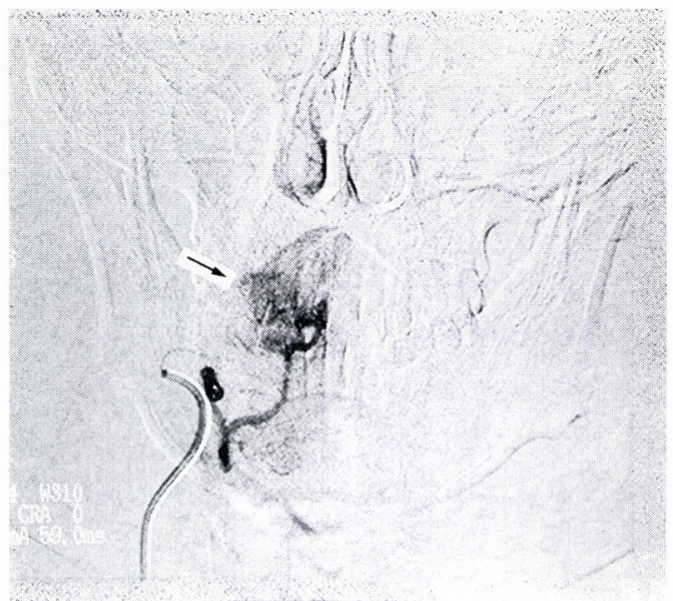

写真 4 舌動脈 DSA 写真 腫瘍血管の増生を認める（矢印）。 


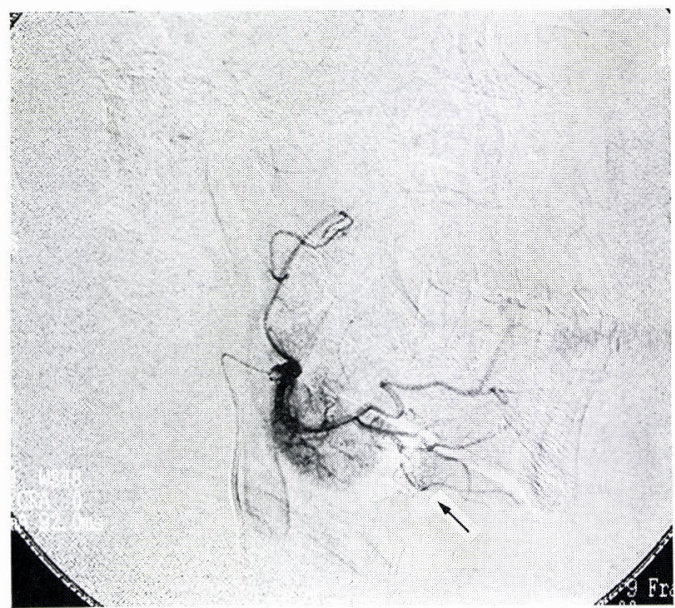

写真 5 顔面動脈 DSA 写真

転移顎下リンパ節が造影されている(矢印)。

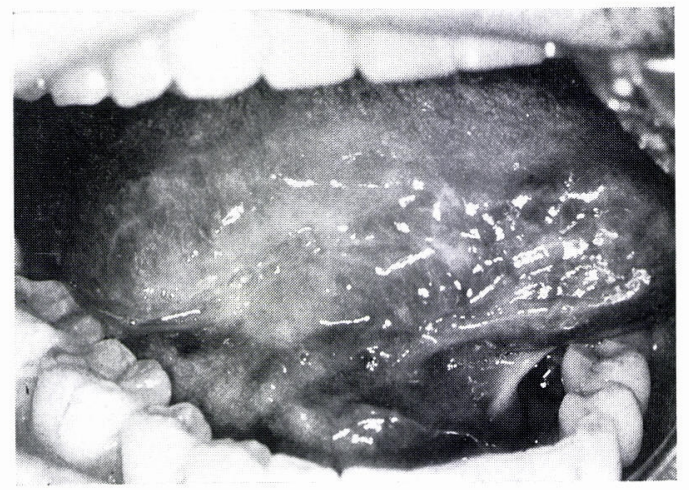

写真 6 手術前原発巣

肉眼的に腫瘍の消失を認める。

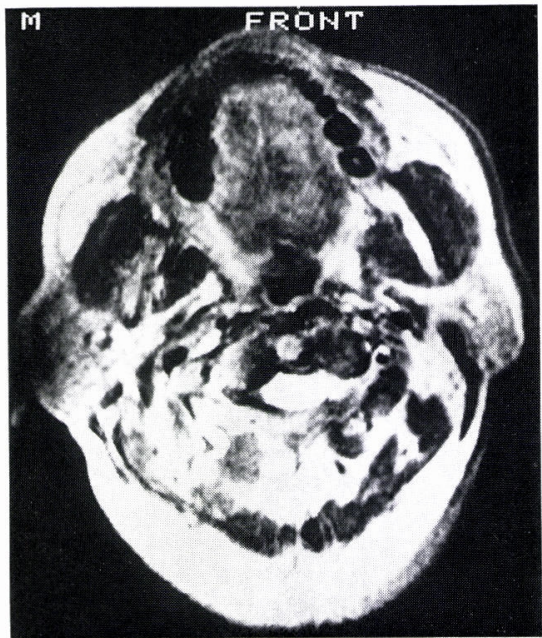

写真 7 手術前 MRI (T2 強調画像)

右舌縁部の高信号域は消失している。

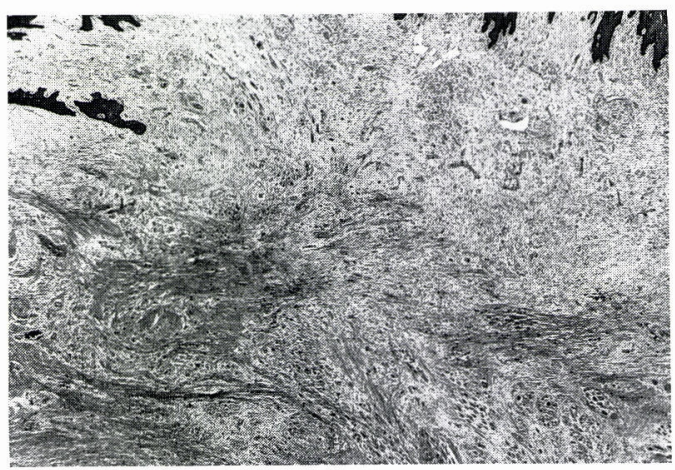

写真 8 原発巣の組織像 腫瘍細胞は消失し線維性結合組織により置 換されていると思われる。

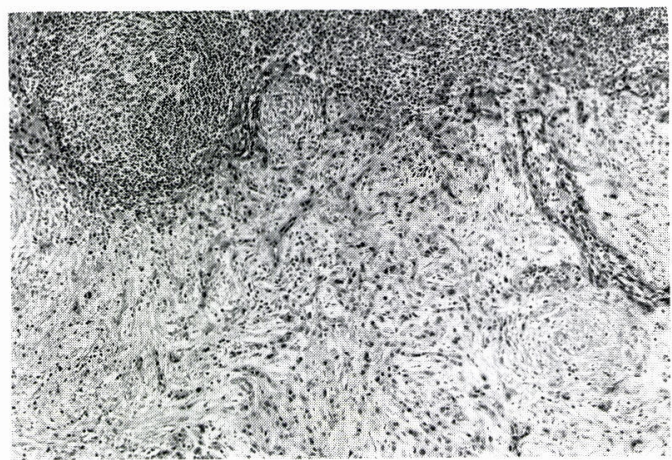

写真 9 転移リンパ節の組織像 腫瘍細胞の残存を認める。

から血流を受けていた（写真 4，5)。CBDCA は舌動脈へ $450 \mathrm{mg}$, 顔面動脈へ $160 \mathrm{mg}$, 後頭動脈 へ90mg が注入された。

経過：原発巣 $\mathrm{CR}$ (写真 6,7 ), 頸部転移巣 $\mathrm{NC}$ と判定し, 舌部分切除術と根治的頸部郭清術 を行った。切除標本の病理組織学的検索で原発巣 に腫瘍の残存はみられなかった。しかし，頸部リ ンパ節には viable な腫瘍細胞の残存を認めた。 大星・下里分類で，原発巣 Grade IV，頸部転移 单 Grade I と判定した（写真 8，9）。治療終了 後 1 年を経過し, 再発, 転移を示唆する徴候を認 めていない。DSA と動注操作による副作用の発 現は認められず，血小板減少 grade 0 , 白血球減 少 grade 2, 口内炎が grade 3 であった。

症例 $2: 70$ 歳, 男性。頓粘膜癌, 組織学的には 高度分化型扁平上皮癌 で， T4N1M0 (写真 10 , 11，12）であった。6 MV X線を(1.5+1.5) Gy/ 日，5回/週，照射野 $10.6 \times 7.6 \mathrm{~cm}$ で総量 $60 \mathrm{~Gy}$ 


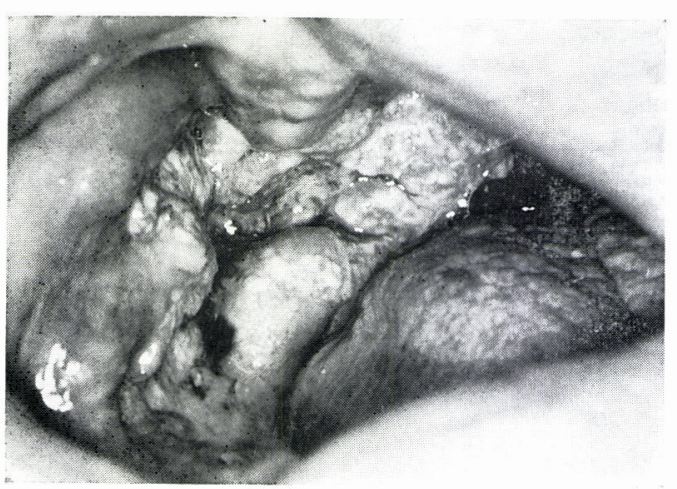

写真 10 右臼後部周囲の進展癌

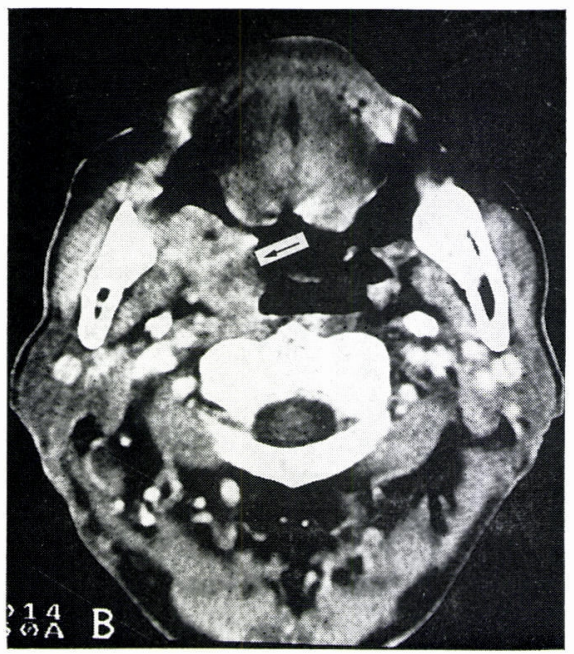

写真 11 治療前造影 CT 写真

副咽頭腔へ進展する腫瘍が不規則に造影 されている (知印)。

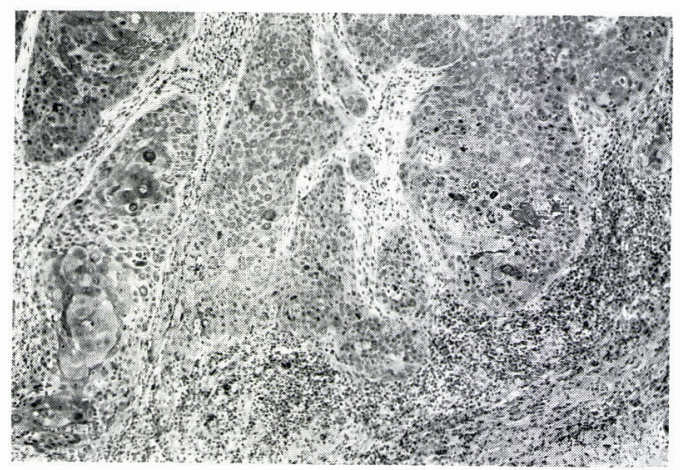

写真 12 高分化型扁平上皮癌

外部照射し, CBDCA $600 \mathrm{mg}$ の動注と UFT ${ }^{\circledR}$ $400 \mathrm{mg}$ /日を連日内服投与した。

DSA 所見：原発腫瘍は舌顔面動脈之その分枝 である上行口蓋動脈および顎動脈とその分枝の煩

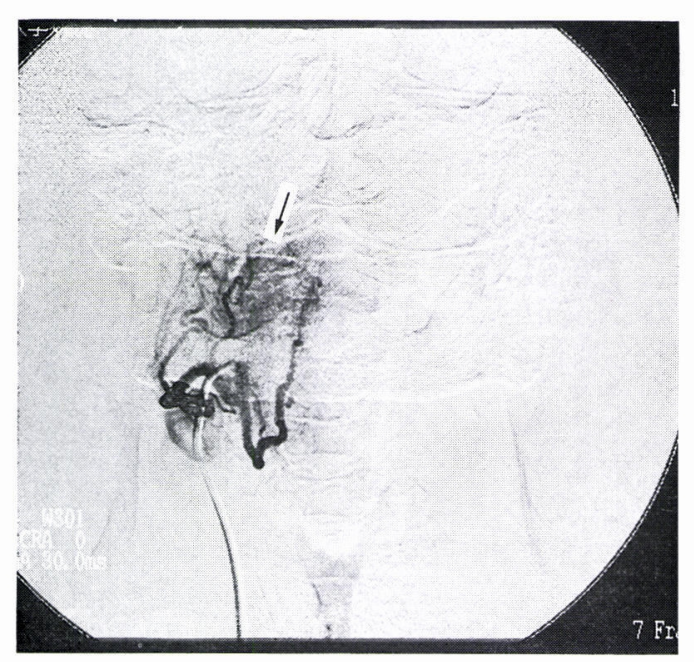

写真 13 舌顔面動脈 DSA 写真 豊富な腫瘍血管を示す (知印)。 舌動脈と顔面動脈は共通幹より起きてい る。

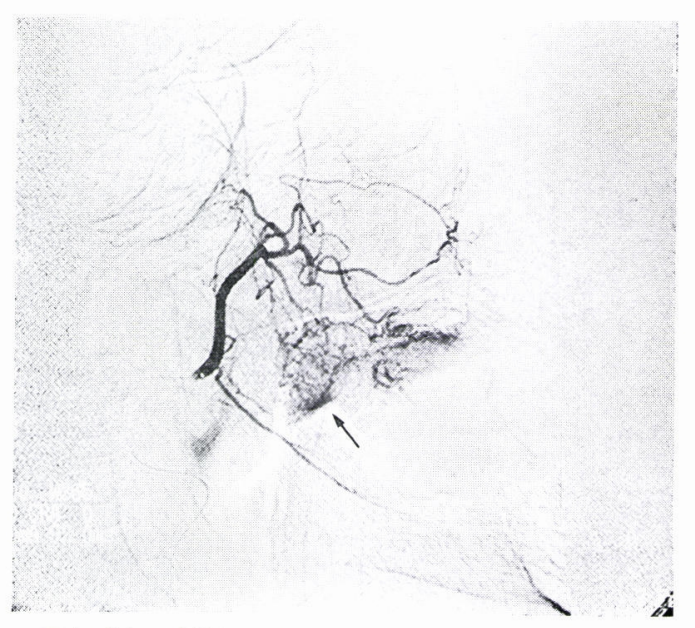

写真 14 顎動脈 DSA 写真

腫瘍血管網を示寸 (矢印)。

動脈から血流を受けていた。副咽頭腔の転移り ンパ節は明らかな支配動脈を確認できなかった。 CBDCA は舌顔面動脈へ300mg, 顎動脈へ300mg が注人された (写真13，14）。

経過：本治療により原発巣, 頸部転移巣ともに CR（写真15，16）となった。治療後，薬剤投与 とは無関係と思われる重篤な潰瘍性大腸炎が発現 し, 全身状態の悪化をみたこともあり, 手術は行 わず経過観察した。治療終了後 1 年を経過した現 在, 再発, 転移の徵候を認めていない。副作用は 血小板減少 grade 1 , 白血球減少 grade 2 , 口 


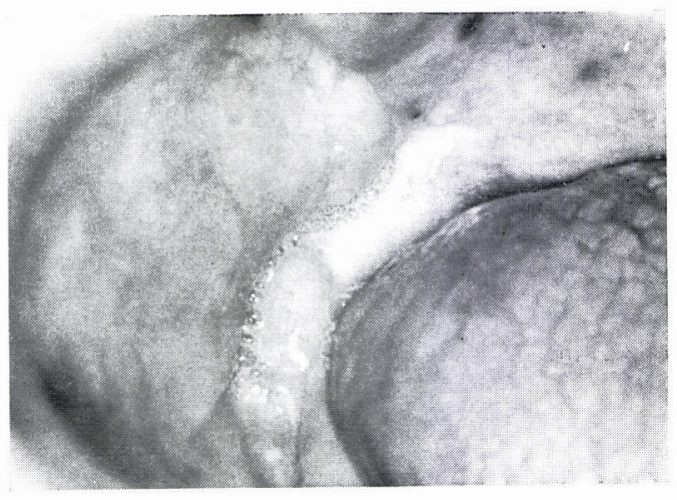

写真 15 治療後原発巣 肉眼的に腫瘍は消失している。

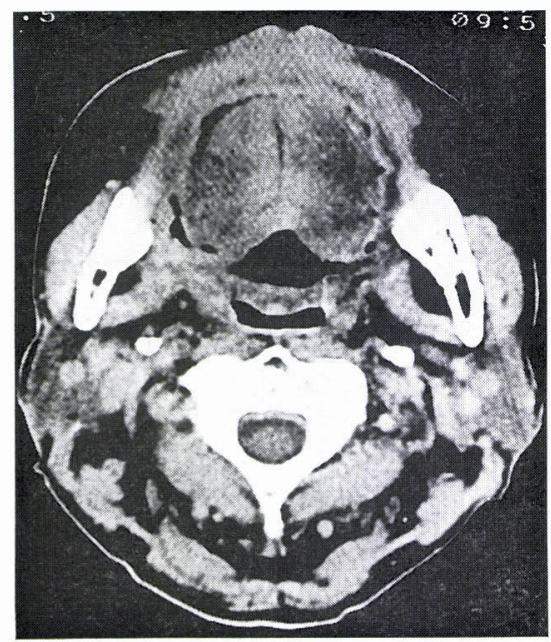

写真 16 治療後造影 CT 写真 不規則に造影された異常像は消失し, ほ ぼ左右詨称となっている。

内炎が grade 3 であった。

\section{考察}

抗癌剂を動脈内一投与寸る目的は抗腫瘍効果の 増強と副作用の軽減である ${ }^{1}$ 。口腔領域の悪性腫 瘍に対する動注療法は浅側頭動脈からの持続動注 療法がその中心をなすが，目的とする動脈への到 達の確実性，カテーテルの血栓形成や留置動脈か らの脱落などのトラブル，患者の日常生活の制限 といった問題を有している。頭頸部癌を対象とし た Seldinger 法による動注療法は過去に越智2), 真里谷 ${ }^{3)}$, Robbins $5^{4)}$ ，半田 $5^{5,6)}$ の報告があ る。本療法は腫瘍を支配する血管から抗癌剂の確 実な投与が可能である。また，カテーテルを留置
しないことからこれに関連するトラブルがなく， one-shot で薬剤を投与するため高濃度の薬剤を 腫瘍組織に分布させることができる。さらに複数 の血管に腫瘍が支配されている場合においても各 血管から抗癌剂の投与が可能であるといった利点 を有している。

CBDCA は主として濃度依存性に抗腫瘍効果 を発揮する薬剂であり，その抗腫瘍効果は蛋白非 結合型プラチナによってもたらされるため，動脈 内投与によりその効果が十分に得られると思われ $\Xi^{7}$ 。また，本薬剤は放射線抵抗性である低酸素 細胞に対して増感作用があるとされ，さらに放射 線障害からの回復に対して阻害作用を有する ${ }^{8)}$ と されており，放射線照射と併用することがより治 療効果を増強すると考えられる。投与時間につい て宮崎ら ${ }^{9)}$ は，子宮癌の実験モデルから CDDP の動注時間は30分閒が適切であると報告し, 半田 $ら^{5,6)}$ は頭頸部癌に対して20分間で動注している。 一方，抗癌剂の動注により動脈の狭小化や時に閉 塞が生じることが報告されておうう ${ }^{10,111}$ ，上田ら ${ }^{121}$ は血管内膜の保護の目的で動注後にステロイド剂 を投与することの有用性を報告している。半田 $ら^{5,6)}$ も頭頸部癌の動注後にステロイド剤を投与 している。私たちも過去の報告に従い投与時間を 設定し，動注終了後にステロイド剤を注入した。

$\mathrm{UFT}^{\circledR}$ は抗癌剤として作用する effector であ る 5 -FU と，それ自身では抗癌活性を示さない で，5-FU の抗癌効果を増強させる modulator としての uracil が配合された薬剤である。他方, CDDP は DNA 合成阻害により抗腫瘍効果を発 現するが，細胞内で還元型葉酸プールの上昇をも たらすことから，5-FU と併用した場合に $5 \cdot \mathrm{FU}$ の DNA 合成阻害が増強されるとされている ${ }^{13)}$ 。 このような biochemical modulation による効果 を期待して UFT ${ }^{\circledR}$ の内服投与を併用した。

今回良好な一次治療効果が得られたことで, 本 治療法は進行癌に対して考慮する価值のある治療 法であると思われた。真里谷ら ${ }^{31}$ は stage $1 ， 2$ の早期癌 4 例を含む頭頸部癌36例の原発巣の CR 率66\%，リンパ節転移巣の $\mathrm{CR}$ 率62\% と原発巣， 転移巣ともに良好な治療成績を報告している。半 田 ${ }^{6)}$ は stage 1，20早期癌 5 例を含む26例の 頭頸部癌を対象として原発巣の $\mathrm{CR}$ 率 $62 \%$ ，転 
移巣の $\mathrm{CR}$ 率 $31 \%$ と原発巣に比して転移巣の効 果が劣る結果を報告している。治療効果に影響を 及ぼす要因として放射線照射量, 動注回数の違い に加えて, 原発巣と転移巣の支配動脈が異なる場 合の薬剤量の分割割合があげられる。本報告の症 例 1 のリンパ節転移巣の治療効果が不良であった 原因として, 原発巣に CBDCA 総量の 3 分の 2 が注入され，さらに転移リンパ節が複数個認めら れたため, 各転移巣への注入量が減少したことが 考えられた。

CBDCA の dose limiting factor は血液毒性, なかでも血小板減少であるが, 報告例の血小板減 少の程度は当科で過去に行った CBDCA 静注と 放射線照射併用例の減少程度と比較すると軽度で あった。動脈内に薬剤を注入することにより，最 初に高濃度の薬剤が腫瘍組織に分布し，全身に循 環するときにはそれより低濃度となることが考え られ，全身的な副作用が軽減されるといわれてい る ${ }^{1,14)}$ 。しかしながら，局所的副作用としての口 内炎は増悪しやすい傾向にあり，口内炎の対策が 課題と思われた。エレースアイスボール 療法は Mahood ら ${ }^{15)}$ の $5-\mathrm{FU}$ による口内炎に対する水 小片による冷却療法を基に大山ら ${ }^{16)}$ により考案さ れた治療法である。本療法は薬㶡性ならびに放射 線性口内炎に対して症状の緩和と炎症からの回復 に有効であることが報告されている ${ }^{16,17)}$ 。報告症 例について使用した結果，炎症の程度の悪化を防 ぐことはできなかったものの，疼痛や口腔乾燥感 の緩解や炎症からの粘膜の回復期間の短縮に関し て有用性を認めた。

本療法の欠点としては DSA を行える施設が必 要であり，栄養血管が同定できない場合に有效性 が予測できないといった点があげられる。当科で も頸部再発癌症例において支配血管の同定が不可 能であったことを経験している。今後，腫瘍の支 配血管以外の血管を塞栓することにより血流の変 更を行ったうえで抗癌剤を動注する等の工夫を加

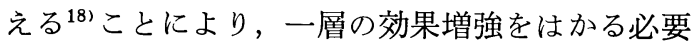
がある。また, 適切な放射線照射量, 動注単独で の治療効果との比較などが検討課題であると考え る。
本論文の要旨は第14回日本口腔腫瘍学会（1996年 1 月 31日，鎌倉市）に抢いて発表した。

\section{文献}

1）田口鉄男：動注化学療法の 理論と実際一薬物動態 力学的研究の重要性一. 癌と化学療法 11:17171728, 1984.

2）越智健太郎：経皮的にセルディンガー法を用いる超 選択的動注療法.耳鼻 $35: 777-783,1989$.

3）真里谷 靖, 渡辺定雄, 横山佳明, 他 : 頭頸部癌に 対する放射線照射および Cisplatin One shot 動注 併用療法. 癌の臨床 $36: 675-679,1990$.

4) Robbins KT, Storniolo AM, Kerber C, et al. : Rapid superselective high-dose cisplatin infusion for advanced head and neck malignacies. Head \& Neck 14 : 364-371, 1992.

5）半田 徹, 折田洋造, 秋定 健, 他: 当教室におけ る頭頸部腫瘍に対する動注療法の現状. 耳鼻 臨 床 69 : 100-105, 1994.

6）半田 徹, 折田洋造, 秋定 健, 他 : 頭頸部腫瘍に 対する CDDP CBDCA 併用超選択動注療法の試 み. 頭頸部腫瘍 $21 ： 182-187 ， 1995$.

7）藤田俊生，松岡加津子, 神代 昭, 他 : Cisplatin の静脈および動脈投与時の体内動態. 臨床薬理 19 : 115-116, 1988.

8) Douple EB, Richmond RC, O'Hara JA, et al. : Carboplatin as a potentiator of radiation therapy. Cancer Treat Rev 12:111-124， 1985.

9）宮崎康二, 島田 清, 岡村 均, 他: 子宮癌に対す るシスプラチン動注療法における至適動注速度につ いての検討. Oncology \& Chemotherapy $7: 96-$ 99, 1991.

10) Lucas RJ, Tumacdar O, Wilson GS, et al. : Hepatic artery occlusion following hepatic artery catheterization. Ann Surg $173: 238-243,1971$.

11）村上昌雄, 橋村孝久, 廣田省三, 他 : 肺癌患者に対 する CDDP の気管支動脈内注入療法による気管支 動脈内注入療法による気管支動脈障害. 肺癌 30 : 471-475, 1990.

12）上田英二，佐古正雄，広田省三，他：抗癌剂動注療 法の動脈壁に及ぼす影響一実験的並びに臨床的検 討一。 日本医放会誌 $52: 960-970 ， 1992$.

13）白坂哲彦：5-FU およびその誘導体と CDDP の 併用 Dual biochemical modulation (DBCM). JAMA $13: 21-23,1992$.

14）伊坪真理子, 亀田治男：抗癌剂の動脈内投与一その 実際と各領域における治療の現況一。癌と化学療法 16 : 199-206, 1989.

15) Mahood DJ, Dose AM, Loprinzi CL : Inhivition of fluorouracil-induced stomatitis by oral cryotherapy. J Clin Oncol 9 : 449-452, 1991.

16）大山和一郎，加納康彦，阿久津美百生 : エレースア イスボールによる薬剤性口腔粘膜炎対策. 癌と化学 療法 21:2675-2677, 1994.

17）大山和一郎，海老原敏 : 放射線性口内炎に対する ice-ball cryotherapy の試み. 癌の臨床 $42: 161$ - 
164， 1996.

18）関根達征：進行子宮頸癌に対する金属コイル塞栓法

療法の臨床的検討 日癌治療会誌 $28: 1706-1715$, による血流変更術を併用した術前少量持続動注化学

\title{
Superselective intraarterial infusion chemotherapy with concurrent radiotherapy for advanced oral squamous cell carcinoma : a preliminary report
}

\author{
Ryoichi Oya, Kunio Ikemura, Nobuhiro Oonari* and Hajime Nakata* \\ Department of Oral and Maxillofacial Surgery, School of Medicine, \\ University of Occupational and Environmental Health \\ (Chief : Prof. Kunio Ikemura) \\ * Department of Radiology, School of Medicine, University of \\ Occupational and Environmental Health \\ (Chief : Prof. Hajime Nakata)
}

\begin{abstract}
Superselective intraarterial infusion of carboplatin with concurrent radiotherapy and tegafur, which was administered per os, was performed on two patients with advanced squamous cell carcinoma of the oral cavity. Seldinger's transfemoral technique was used, and the angiographic images of the external carotid artery were obtained. This was followed by a one-shot infusion of carboplatin into the vessels to feed the tumor.

Patient 1 with carcinoma of the tongue (T3N2bM0 stage IV) was treated with an intraarterial infusion of $700 \mathrm{mg}$ carboplatin $(450 \mathrm{mg}$ for primary tumor, $250 \mathrm{mg}$ for metastatic lymph nodes), an irradiation of $30 \mathrm{~Gy}$, an $600 \mathrm{mg}$ UFT per day. The patient showed complete response at the primary site, and there was no change in the metastatic lymph nodes. A histological examination of the resected specimens revealed no tumor cells at the primary site, but viable tumor cells were recognized in the lymph nodes.

Patient 2 with carcinoma of the buccal mucosa (T4N1M0 stage IV) was treated with an intraarterial infusion of $600 \mathrm{mg}$ carboplatin, an irradiation of $60 \mathrm{~Gy}$, and $400 \mathrm{mg}$ UFT per day. The patient showed complete response both at the primary site and in the metastatic lymph node. Resection surgery was not performed.

Both patients showed no evidence of disease during the follow-up period of one year. As this method had a remarkable antitumor effect and slight adverse reactions, it was considered to be a good treatment method for advanced oral carcinomas. This method, however, needs special equipment and an experienced staff for arterial angiography, and its efficacy is unpredictable when an artery to feed the tumor is not found for a certainty.
\end{abstract}

Key words : advanced oral carcinoma, superselective intraarterial chemotherapy, carboplatin, radiotherapy, UFT ${ }^{\circledR}$

Requests for reprints to: Dr. Oya R., Department of Oral and Maxillo-Facial Surgery, University of Occupational and Enviromental Health, Kitakyusyu, Fukuoka, 807 Japan 